\title{
Germination of Cola anomala (K. Shum.) Shott and Endl seeds: effects of provenance, substrate and dehydration
}

\author{
Gabriel KANMEGNE ${ }^{1 *}$, Mariette ANOUMA'A ${ }^{1}$, FOTSO ${ }^{2}$, Hermann Désiré \\ MBOUOBDA $^{2}$, Delphine Ache MBIBONG ${ }^{1}$ and Dénis Ndoumou OMOKOLO ${ }^{3}$ \\ ${ }^{I}$ Department of Plant Biology, Faculty of Science, University of Dschang, P.O. Box 67 Dschang, Cameroon. \\ ${ }^{2}$ Department of Biology, Higher Teacher's Training College of Bambili, \\ University of Bamenda, P.O. Box 39 Bamenda, Cameroon. \\ ${ }^{3}$ Department of Biological Sciences, Higher Teacher's Training College, \\ University of Yaoundé I, P.O. Box 47 Yaoundé, Cameroon. \\ "Corresponding author, E-mail: gkanmegne@yahoo.fr; Tel: + (237) 677490069
}

\begin{abstract}
As a step in the process of Cola anomala domestication, investigations were undertaken on germination requirements and desiccation tolerance of its seeds. Three seed provenances (Bamenda, Bayangam and Dschang), three substrates (forest top soil, river sand and a mixture of forest top soil and river sand) and two photoperiods (12 hours/day and, continuous darkness) were investigated for their effects on seed germination. To evaluate their desiccation tolerance, fresh seeds were dried at room temperature for 16 days during which seed moisture content, seed germination percentage and electrical conductivity of seed leachate were monitored at two-day intervals. Results showed that germination percentages were significantly $(P<0.05)$ higher both on forest top soil alone $(86.04 \pm 4.8 \%)$, and on a mixture of forest top soil and river sand $(83.56 \pm 4.5 \%)$, than on river sand alone $(69.96 \pm 4.7 \%)$. Seeds from Bamenda showed a higher germination percentage $(91.4 \pm 4.7 \%)$ than those from either Bayangam $(77.36 \pm 4.7 \%)$ or Dschang $(70.8 \pm 4.8 \%)$. The desiccation tolerance test revealed that as response to drying, the mean germination percentage was first slightly reduced as moisture was lost, then declined considerably at moisture content below 50.28\%. Total germination failure was observed when seed moisture reached $32.24 \%$. Electrical conductivity of seed leachate exhibited a strong correlation with loss of viability as well as with desiccation. It is concluded that there is a provenance-related variation in C. anomala seed germination. The best substrate for germination is forest top soil supplemented or not with river sand in a $1 / 1(\mathrm{v} / \mathrm{v})$ ratio. C. anomala seeds are desiccation-sensitive and their storage behaviour is recalcitrant.
\end{abstract}

() 2015 International Formulae Group. All rights reserved.

Keywords: Desiccation tolerance, critical moisture, lethal moisture, electrical conductivity, electrolyte leakage, storage behaviour.

\section{INTRODUCTION}

Cola is a tropical African genus that belongs to the Sterculiaceae family (Russel, 1955). The genus comprises about 140 species, but the most commonly used are Cola nitida (Vent.) Schott and Endl, Cola acuminata (Pal. de Beauv) Schott and Endl and Cola anomala (K. Schum) Shott and Endl 
(Russel, 1955; Mabberley, 2008). These three species are cultivated by subsistence farmers in association with cacao and/or coffee as shade plants, for their edible seeds commonly called kola nuts (Duke, 2001). Kola nut has for hundreds of years served as an important article of internal trade in Nigeria and other parts of Africa (Asogwa et al., 2012a). It has been an item of trade in West Africa and in the Trans-Saharan trade routes for many centuries (Gebissa, 2006). The spread of kola nuts has resulted from its reputation as a stimulant, increasing energy and strength, dispelling drowsiness and staving off hunger. These properties have been attributed to the large amounts of caffeine and smaller amounts of the obromine, kolatin and glucose it contains, all of which act as stimulants and may be mildly addictive (Blades, 2000; Niemenak et al., 2008). It is also used to flavor drinks and in the manufacture of pharmaceuticals, and it is exported to Europe and North America for these purposes (Burkill, 2000). The most recent and remarkable advancement in kola by-product utilization is the use of kola pod husks in the replacement of up to $60 \%$ of the maize used in the formulation of poultry feed (Hamzat and Babatunde, 2001). Kola nut is one of the many non-timber forest products that are of socio-economic importance. Its commercialization in both the domestic and national markets raises the standard of living of those involved in its trading activities (Gebissa, 2006; Asogwa et al., 2012b).

Given the socio-economic importance and the possibility of growing these trees in farms, Cola sp (C. anomala, C. acuminata and C. nitida) have been suggested as candidates for domestication by agro forestry. As an important step in the process of domestication of these species which constitute a vital resource for millions of people in sub-Saharan Africa, research on seed germination physiology is needed. There have been some attempts to domesticate Cola species, but this concerned only $C$. nitida and $C$. acuminata.
For these two species, seed handlings, plant regeneration through seeds, and vegetative propagation have been widely studied (Famaye et al., 2007; Mbete et al., 2011). However, for $C$. anomala very little has been studied on the process of plant regeneration, and the characteristics of seed germination have not been documented to date. Moreover, classification of seed storage behaviour has not been made for this last species. Indeed, among the different species of Cola producing edible nuts, Cola anomala has suffered neglect in the areas of research and development despite its socio-economic importance.

As an important step in the process of Cola anomala domestication, this work was undertaken to determine: 1) the influence of three important factors (provenance, photoperiod and substrate) on the germination of seeds, and 2) the desiccation sensitivity and storage behaviour classification of seeds.

\section{MATERIALS AND METHODS \\ Seed material}

Seeds used in the present study originated from three localities situated in the western highlands of Cameroon: Bayangam $\left(5^{\circ} 18^{\prime} \mathrm{N}, 10^{\circ} 29^{\prime} \mathrm{E}\right.$, altitude $\left.1500 \mathrm{~m}\right)$, Bamenda $\left(5^{\circ} 47^{\prime} \mathrm{N}, 10^{\circ} 10^{\prime} \mathrm{E}\right.$, altitude $\left.1300 \mathrm{~m}\right)$ and Dschang $\left(5^{\circ} 27^{\prime} \mathrm{N}, 10^{\circ} 3^{\prime} \mathrm{E}\right.$, altitude $\left.1400 \mathrm{~m}\right)$. In each locality, mature and disease-free pods were harvested from a minimum of 10 randomly selected trees in March 2012. A minimum of 100 pods (containing 1 to 10 seeds each) were harvested from each site and immediately brought to the Laboratory of Applied Botany, Department of Plant Biology, University of Dschang. In the laboratory, seeds were extracted from pods 24 hours after harvest and processed by removing their white and soft testa to obtain red or pink coloured fresh nuts, which were used for further experiments. 


\section{Germination assay}

Seeds from each provenance were sown in black plastic perforated polythene bags (20 $\mathrm{cm}$ high and $10 \mathrm{~cm}$ diameter) filled with substrate which was either forest top soil, river sand or a mixture of forest top soil and river sand in $1: 1(\mathrm{v} / \mathrm{v})$ ratio. As light regime (photoperiod) effect was one of the topics of investigation, sowing was done in such a way that $3 / 4$ of the volume of seed was buried in the substrate while the remaining $1 / 4$ was visible above. The seeded polythene bags were then placed in the nursery $\left(22 \pm 3{ }^{\circ} \mathrm{C}\right)$ at two different photoperiods: natural photoperiod (12 hours/day) and continuous darkness. Darkness was provided by placing the seeded polythene bags in wooden boxes $(1 \mathrm{~m} \mathrm{x} 1 \mathrm{~m} x$ $0.5 \mathrm{~m}$ ) whose internal walls were lined with black and thick polythene paper.

To investigate on Cola anomala seed germination, a total of 1350 seeds were sown in three blocks of a split-split plot experimental design. Each main plot contained three substrates (Forest Top soil, River Sand and 1:1 (v/v) mixture of Forest Top soil and River Sand), whereas three different provenances (Bamenda, Bayangam and Dschang) were tested at the subplot level. At the sub-subplot level, two photoperiods (12 hours/day and continuous darkness) were investigated. At each level, treatments were assigned at random to experimental units so as to have 3 substrates $X 3$ provenances $X 2$ photoperiods X 3 replications X 25 seeds. Manually, water was applied daily to the seeded polythene bags using a sprayer, so that the medium (substrate) was kept moist without getting waterlogged. Nuts with radicle protrusions and/or with the emergence of the plumule were recorded as having germinated. The percentage of germination was recorded 20 days after seeding.

\section{Desiccation tolerance test}

Mature seeds harvested from a single tree in Bamenda were used for the desiccation tolerance test. Fresh seeds were extracted from mature pods 24 hours after harvest and processed as described above. They were then spread in a single layer on the laboratory bench top and left to dry under shade at laboratory temperature $\left(25 \pm 2 \quad{ }^{\circ} \mathrm{C}\right)$. Laboratory relative humidity was $55 \pm 5 \%$. Seed samples were withdrawn every 2 days for moisture content measurement, conductivity test and germination test.

Moisture content (MC\%) was determined by the oven dry method which consisted in weighing seeds before and after drying them in the oven at $103{ }^{\circ} \mathrm{C}$ for $17 \mathrm{~h}$. Moisture content, which was expressed as a percentage of fresh weight, was calculated using the following formula:

$M C \%=[(F W-D W) \div F W] \times 100$.

Where FW (fresh weight) is weight of sample before drying and DW (dry weight) is weight of sample after drying (ISTA, 2004). The value of the moisture content for each drying time was the mean of six measurements (six replications of one seed each).

For the conductivity test, a square of seed piece (cotyledon) was cut, weighed and soaked in distilled water in a $100 \mathrm{ml}$ beaker (i.e., $3 \mathrm{~g}$ of seed piece in $50 \mathrm{ml}$ of distilled water). The beaker was covered and left in the laboratory at $25{ }^{\circ} \mathrm{C}$ for $24 \mathrm{~h}$. Two beakers with $50 \mathrm{ml}$ of distilled water, but no seed piece, were treated similarly as blanks to determine the base conductivity of the water. After $24 \mathrm{~h}$, the seed piece was strained from the water and conductivity of the water was measured using a HACH Model of Conductivity/TDS Meter. The mean conductivity of the blanks was subtracted from each sample reading. Conductivities were expressed in microSiemens $(\mu \mathrm{S})$. Six replications were carried out at each drying time.

At 2-day intervals, three replications of 25 seeds were withdrawn for the germination test which was carried out in the nursery at 22 $\pm 3{ }^{\circ} \mathrm{C}$, natural photoperiod (i. e. 12 hours of light per day) and in black polythene bags 
filled with forest top soil as substrate. The seeded polythene bags were then regularly watered and germination percentages were recorded for 20 days as described above.

\section{Statistical analysis}

Data analyses were performed using SPSS 12.0 software package. The dependent variable was the mean germination percentage, whose data were transformed into arcsine square root values before statistical analysis. Analyses of variance (ANOVA) were performed to detect the level of significance of the main effects of parameters such as seed provenance, germination substrate and photoperiod, as well as the significance of their interaction effects. Means that exhibited significant differences $(P<$ 0.05 ) were further compared using Duncan's multiple comparison test or t-test as appropriate.

The 2-tailed Pearson correlation coefficient was used to establish correlations between the different seed variables investigated (moisture content, germination percentage, and electrical conductivity of leachate). The critical water content of seeds was recorded at the point in which the germination significantly decreased while the lethal water content was recorded at the point where there was total failure of germination.

\section{RESULTS}

Analysis of variance (Table 1) showed that the germination percentage was significantly $(P=0.03)$ influenced by substrate and highly significantly $(P=0.003)$ influenced by the provenance. As shown in Table 2, germination percentages were significantly $(P<0.05)$ higher both on forest top soil $(86.04 \pm 4.8 \%)$ and on forest top soil + river sand mixture $(83.56 \pm 4.5 \%)$, than on river sand alone $(69.96 \pm 4.7 \%)$. Seeds from
Bamenda showed a higher germination percentage $(91.4 \pm 4.7 \%)$ than those from either Bayangam $(77.36 \pm 4.7 \%)$ or Dschang $(70.8 \pm 4.8 \%)$. There was no significant difference between the germination percentages of seeds from Bayangam and Dschang. The highest germination percentage $(98.22 \pm 8.2 \%)$ was recorded with seeds from Bamenda sown on forest top soil, while the lowest $(65.2 \pm 8.4 \%)$ was recorded with seeds from Dschang sown on river sand.

Results of the desiccation tolerance test showed that fresh seeds of $C$. anomala with initial moisture content of $67.57 \pm 0.89 \%$ had a germination percentage of $90 \pm 1.15 \%$ and the conductivity of leachate was $30.43 \pm 1.33$ $\mu \mathrm{S}$. When seeds were dried, the germination percentage declined gradually with decreasing moisture content, while the electrical conductivity of leachate increased (Figure 1).

From 0 to 10 days of drying time, the moisture content decreased from $67.57 \pm$ $0.89 \%$ to $50.28 \pm 2.53 \%$ and the germination percentage was maintained between $90 \%$ and $55.33 \%$, meanwhile the electrical conductivity of leachate was maintained between $30.43 \mu \mathrm{S}$ and $53.13 \mu \mathrm{S}$. At moisture content below $50.28 \%$, the germination percentage drastically dropped to $12 \pm 1.15 \%$ at 12 days of drying time. At the same time, the electrical conductivity of leachate abruptly increased to $178.5 \pm 17.7 \mu \mathrm{S}$. The value of $50.28 \%$ was then recorded to be the critical moisture content. After 16 days of drying, the moisture content had reduced to $32.24 \pm 1.08 \%$ and germination was $0 \%$. The value of $32.24 \%$ was consequently recorded as the lethal moisture content. Seed leachate conductivity was highly and negatively correlated both to the germination percentage $(r=-0.93)$ and to moisture content $(r=-0.91)$, meanwhile the germination percentage and moisture content were positively correlated $(r=0.98)($ Table 3$)$. 
Table 1: ANOVA of the effects of substrate, photoperiod, seeds provenance and their interactions on mean germination percentage of $C$. anomala seeds at 20 days after sowing.

\begin{tabular}{cccc}
\hline Effect & DF & $\boldsymbol{F}$-value & $\boldsymbol{P}$-value \\
\hline $\mathrm{S}$ & 2 & 3.39 & 0.03 \\
$\mathrm{Ph}$ & 1 & 3.29 & 0.07 \\
$\mathrm{Pr}$ & 2 & 5.94 & 0.003 \\
$\mathrm{~S} \times \mathrm{Ph}$ & 2 & 0.64 & 0.52 \\
$\mathrm{~S} \times \mathrm{Pr}$ & 4 & 0.32 & 0.85 \\
$\mathrm{Ph} \times \mathrm{Pr}$ & 2 & 0.69 & 0.5 \\
$\mathrm{~S} x \mathrm{Ph}$ x Pr & 4 & 0.1 & 0.98 \\
\hline
\end{tabular}

Notes: DF, Degree of freedom; S, substrate; Ph, photoperiod; Pr, provenance; $\mathrm{S}$ x Ph, substrate $\mathrm{x}$ photoperiod interaction; $\mathrm{S}$ x $\mathrm{Pr}$, substrate $\mathrm{x}$ provenance interaction; $\mathrm{Ph} \times \mathrm{Pr}$, photoperiod $\mathrm{x}$ provenance interaction; $\mathrm{S} \times \mathrm{Ph} \times \mathrm{Pr}$, substrate $\mathrm{x}$ photoperiod $\mathrm{x}$ provenance interaction

Table 2: Germination percentages of $C$. anomala seeds from different provenances 20 days after sowing on different germination substrates.

\begin{tabular}{|c|c|c|c|c|}
\hline \multirow[b]{2}{*}{ Provenance } & \multicolumn{3}{|c|}{ Substrate } & \multirow[b]{2}{*}{$\begin{array}{c}\text { Provenances' } \\
\text { main effect }\end{array}$} \\
\hline & Top soil & $\begin{array}{c}\text { Top soil + River } \\
\text { sand }\end{array}$ & River sand & \\
\hline Bamenda & $98.22 \pm 8.2^{\mathrm{a}}$ & $98.0 \pm 8^{\mathrm{a}}$ & $78.0 \pm 8.2^{\mathrm{a}}$ & $91.4 \pm 4.7^{\mathrm{a}}$ \\
\hline Bayangam & $82.4 \pm 8.2^{\mathrm{b}}$ & $83.0 \pm 8.2^{\mathrm{b}}$ & $66.7 \pm 8^{\mathrm{b}}$ & $77.3 \pm 4.7^{\mathrm{b}}$ \\
\hline Dschang & $77.5 \pm 8.4^{\mathrm{b}}$ & $69.7 \pm 8.2^{\mathrm{b}}$ & $65.2 \pm 8.4^{\mathrm{b}}$ & $70.8 \pm 4.8^{\mathrm{b}}$ \\
\hline Substrates' main & $86.04 \pm 4.8$ & $83.56 \pm 4.5$ & $69.96 \pm 4.7$ & \\
\hline \multirow[t]{2}{*}{ effect } & \multicolumn{2}{|c|}{ ns } & & \\
\hline & & . & & \\
\hline
\end{tabular}

Notes: Within the same column, means \pm SEM followed by the same letter(s) are not significantly different at the 5\% level according to Duncan multiple comparison test. ns, no significant difference between Top soil and Top soil+River sand mixture; *Significant difference at $5 \%$ level between River sand and the two other substrates.

Table 3: Two tailed Pearson correlation coefficients between different Cola anomala's seeds parameters.

\begin{tabular}{lccc}
\hline & Moisture content & Conductivity & Germ. percentage \\
\hline Moisture content & 1 & $-0.915^{* *}$ & $0.983^{* *}$ \\
Conductivity & 1 & $-0.937^{* *}$ \\
Germ. percentage & & 1 \\
\hline **, correlation is significant at $\mathrm{p} \leq 0.01$. & &
\end{tabular}




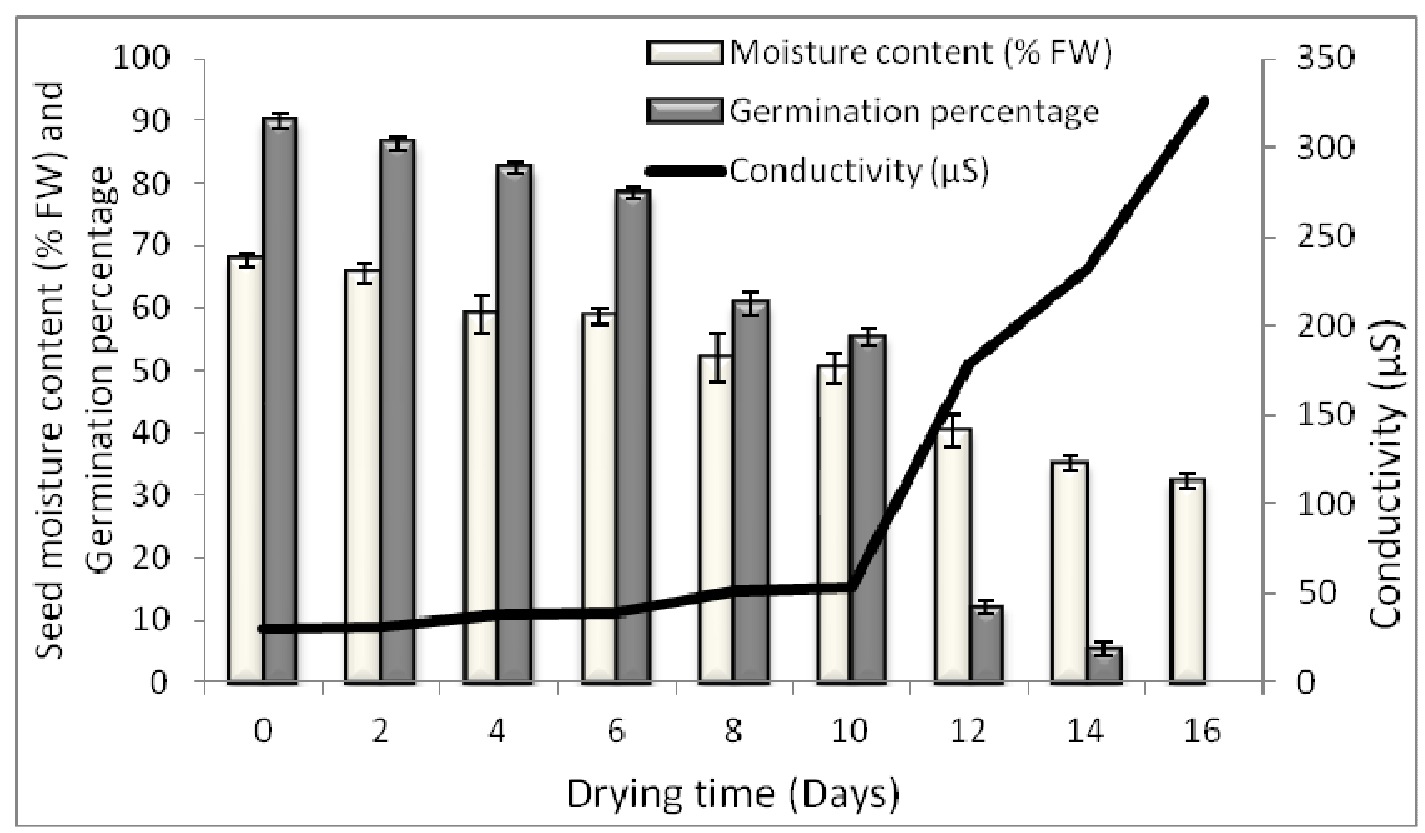

Figure 1: Variation in moisture content, germination percentage and leachate conductivity of Cola anomala seeds during drying.

\section{DISCUSSION}

Seed provenances have displayed significant differences in germination percentages of $C$. anomala seeds. Some authors (Loha et al., 2006) showed a relatively low correlation between seed provenances and their germination parameters. In most plant species nevertheless, seeds vary in their degree of germinability between and within populations and between and within individuals (Bischoff et al., 2006; Kanmegne and Omokolo, 2008). Some of this variation has been suggested to be of genetic origin (Bischoff et al., 2006), but much of it is known to be phenotypic, caused by the local conditions under which the seed matured (Cedan et al., 2013). Indeed, germination characteristics are not only affected by the current environmental conditions but also by conditions experienced by the mother plants in the previous generation (Khurana and Singh, 2001; Fenner and Thompson, 2005). Nevertheless, it cannot be concluded from the present study which factor (topographic or climatic characteristics of locations or genetic characteristics of mother trees) caused the provenance-related variation in Cola anomala seeds germination.

One of the most significant factors for seed germination in the nursery is the type of substrate. A substrate needs to have adequate aeration and moisture for germinating seeds (Khurana and Singh, 2001). The results of the present study showed that forest top soil and a mixture of forest top soil and river sand showed a higher germination percentage compared to river sand alone. As seeds were only partially buried, there was no problem of seed aeration. The differences among different substrates for their germination percentage as reported here may be attributed to the differences in moisture retention. It is well known that both forest top soil and the mixture of forest top soil and river sand have higher moisture retention capacity than river sand alone. Germination of $C$. anomala seeds 
may have been enhanced by the constantly moist condition, which is not possible in sand. Similar results have been reported for seeds of many others species (Benvenuti, 2003; Rodriguez et al., 2014), although ISTA (2004) has suggested sand as a suitable medium for seed germination in some species.

In relation to the desiccation sensitivity test, the moisture content value of $67.57 \%$ recorded for fully matured fresh seeds of Cola anomala was very high. According to MSBP (2002), such moisture content indicates that seeds are potentially immature or are in the post abscission phase. This is however applicable to orthodox seeds which go through the process of maturation drying. Recalcitrant seeds on the contrary do not undergo maturation drying and even after shedding from the mother plant they have high moisture content ranging from 30 to $70 \%$, leading to their wetness (Martins et al., 2003; MSBP, 2005).

The capability of seeds to germinate was greatly affected by moisture content. Seeds with high initial moisture content $(67.57 \%)$ showed a maximum germination percentage $(90 \%)$. The mean germination percentage then declined as the moisture content decreased, and below $32.24 \%$ moisture content there was no seed germination. The loss in mean germination percentage as a result of seed dehydration indicated that $C$. anomala seeds can be categorized as desiccation-sensitive. This was not surprising, since $C$. anomala seeds exhibit most of the characteristics of recalcitrance such as being fleshy, large in size and produced from plants growing in the humid forest environment (Thomsen, 2000). When fresh recalcitrant seeds begin to dry, their viability is first slightly reduced as moisture is lost, but begins to decline considerably at a certain moisture level termed the critical moisture content or lowest safe moisture content (Walters et al., 2001; Wesley-Smith et al., 2001). The value of $50.28 \%$ recorded in the present study as the critical moisture content is higher than those reported for many other recalcitrant tree seeds such as Garcinia kola seeds (Agyili et al., 2007; Asomaning et al., 2011) and Corypha umbraculifera seeds (Viji et al., 2013), but similar to values which have been reported for Archontophoenix alexandrae (Martins et al., 2003) and Euterpe edulis (Panza et al., 2007) seeds. This is an indication that the critical moisture content of recalcitrant seeds varies greatly among species.

Electrical conductivity of seed leachate exhibited a strong correlation with loss of viability as well as with desiccation. This indicates that measurement of leachate conductivity can be considered as a valuable tool for viability test in $C$. anomala seeds, as previously reported for many others species as Garcinia kola (Asomaning et al., 2011) and Vicia sativa (Samarah, 2006). Electrolyte leakage increased abruptly as seeds were dried below the critical moisture level and reached its maximum value at the lethal moisture level, corroborating results obtained from seeds of Euterpe edulis (Panza et al., 2007) and Syzygium cuminii (Abbas et al., 2003).

It has been suggested that there is a linear relationship between seed desiccation and membrane damage, while electrical conductivity and membrane damage are also directly correlated events (Khan et al., 2003). Indeed, electrolyte leakage from tissues can be used to indicate the effectiveness of membranes as barriers to solute diffusion. While relatively low levels of leakage indicate that cellular membranes are semi permeable, high levels of leakage indicate damage to membranes (Sacandé et al., 2001). Many studies provide evidence that if dehydration stress disrupts membrane integrity in desiccation sensitive seeds, then increases in 
the amount of solutes leaked may be detectable in response to dehydration, and these increases should be associated with loss of viability (Walters et al., 2001; WesleySmith et al., 2001). The results presented here are complementary to these findings and clearly indicates that cellular membranes of desiccation-sensitive Cola anomala seeds may have been damaged as seeds were dried further as observed in the increases in the levels of solute leakages. Excessive dehydration of the seeds beyond the critical moisture content may have severely disrupted the integrity of the cellular membranes of seed tissues, resulting in the uncontrollable rate of solute losses from seeds. This is consistent with the concepts that membranes in desiccation-sensitive seeds are damaged by dehydration below the critical moisture content and are unable to reform completely during imbibitions (Kernode and FinchSavage, 2002; Berjak et al., 2007).

\section{Conclusion}

The $C$. anomala seeds are clearly desiccation-sensitive, with $50.28 \%$ and $32.24 \%$ as values of the critical and the lethal moisture contents respectively. Loss in seed viability during dehydration was found to be associated with increased electrolyte leakage, following the disruption of cellular membranes integrity. For propagating $C$. anomala from seeds, it is recommended that fresh seeds from mature pods be sown without being previously dried, and that seeding be done in substrate composed of either forest top soil or a mixture of forest top soil and river sand in a 1:1 (v/v) ratio.

\section{REFERENCES}

Abbas M, Khan MM, Iqbal MJ, Fatima B. 2003. Studies on Jaman (Syzygium cuminii L. Skeels) seed storage behavior. Pak. J. Agric. Sci., 40: 164-169.
Agyili J, Sacande M, Koffi E. 2007. Improving the collection and germination of West African Garcinia kola Heckel seeds. New Forest, 34: 269279.

Asogwa EU, Agbongiarhuoyi AE, Mokwunye FC, Ndagi I, Adebiyi S, Ndubuaku TCN. 2012a. The challenges of kolanuts processing, trade and export from Nigeria and other sub-Saharan African countries. Int. J. Sci. Nature, 3(1): 6-11.

Asogwa EU, Otunde AH, Oluyole KA, Ndubuaku TCN, Uwagboe EO. 2012b. Kolanuts production, processing and marketing in the South Eastern states of Nigeria. Am-Euras J. Agric. Environ. Sci., 12(4): 463-468.

Asomaning JM, Olympio NS, Sacande M. 2011. Desiccation sensitivity and germination of recalcitrant Garcinia kola Heckel seeds. Res. J. Seed Sci., 4(1): 1527.

Benvenuti S. 2003. Soil texture involvement in germination and emergence of buried weed seeds. Agron. J., 95: 191-198.

Berjak P, Farrant JM, Pammenter NW. 2007. Seed desiccation-tolerance mechanism. In Plant Desiccation Tolerance, Jenks MA, Wood AJ (eds). Blackwell Publishing: Ames; 151-192.

Bischoff A, Vonlanthen B, Steiner T, MullerScharer H. 2006. Seed provenance matters - Effects on germination of four plant species used for ecological restoration. Basic Appl. Ecol., 7: 347359.

Blades M. 2000. Functional Food or Neutraceutics. Nutr. Food Sci., 30(2): 73-75.

Burkill HM. 2000. The Useful Plants of West Tropical Africa (vol.5). Royal Botanic Gardens: Kew.

Cedan C, Sampedro L, Zas R. 2013. The maternal environment determines the 
timing of germination in Pinus pinaster. Environ. Exp. Bot., 94: 66-72.

Duke JA. 2001. Handbook of Nuts. Boca Raton Fe CRC Press: Florida.

Famaye AO, Oloyede AA, Adeyemi EA. 2007. Stem-cutting size of kola (Cola indica). Trop. Sci., 47(1): 43-44.

Fenner M, Thompson K. 2005. The Ecology of Seeds. Cambrigde University Press: Cambrigde.

Gebissa E. 2006. Kola is God's gift: agricultural production, export initiatives and the kola industry in Asante and the Gold Coast c. 1820-1950 (review). Afr. Studies Rev., 49(3): 94-96.

Hamzat RA, Babatunde BB. 2001. Performance characteristics of broiler finishers feed kola (Cola nitida) Vent (Schott and Endl.) pod husk-based diets. Moor. J. Agric. Res., 2(2): 153-158.

ISTA (International Seed Testing Association). 2004. International Rules for Seed Testing. Rules 2004. International Seed Testing Association: Zurich.

Kanmegne G, Omokolo ND. 2008. Germination of Garcinia kola (Heckel) seeds in response to different hormone treatments. Fruits, 63: 155-161.

Kernode AR, Finch-Savage WE. 2002. Desiccation sensitivity in orthodox and recalcitrant seeds in relation to development. In Desiccation and Survival in Plants: Drying without Dying, Black M, Pritchard HW (eds). CABI Publishing: Wallingford; 149-184.

Khan MM, Alam MA, Abbas M, Iqbal MJ. 2003. Studies on desiccation tolerance in four Citrus species. Pak. J. Agric. Sci., 40: $55-62$.

Khurana E, Singh JS. 2001. Ecology of seeds and seedling growth for conservation and restoration of tropical dry forest: a review. Environ. Conserv., 28: 39-52.
Loha A, Tigabu M, Teketay D, Lunkvist K, Fries A. 2006. Provenance variation in seed morphometric traits, germination and seedling growth of Cordia africana Lam. New Forests, 32: 71-86.

Mabberley DJ. 2008. Mabberley's Plantbook: a Portable Dictionary of Plants, their Classification and Uses ( $3^{\text {rd }}$ edn). Cambrigde University Press: New York.

Martins CC, Bovi MLA, Nakagawa J. 2003. Desiccation effects on germination and vigor of King palm seeds. Hortic. Braz. 21(1): 88-92.

Mbete P, Makosso S, Lelou B, Douh C, Ngokaka C. 2011. Study of vegetative multiplication of Cola nitida by layering technique in Conga Brazzaville. J. Appl. Biosci., 37: 2485-2490.

MSBP (Millenium Seed Bank Project). 2002. Seed conservation technique course. Proceedings of measuring seed moisture. September 9-20. Royal Botanic Gardens: Kew.

MSBP (Millenium Seed Bank Project). 2005. Post Harvest Handling. Technical Information Sheet 4. Royal Botanic Gardens: Kew.

Niemenak N, Onomo PE, Fotso, Lieberei R, Ndoumo DO. 2008. Purine alkaloids and phenolic compounds in three Cola species and Garcinia kola grown in Cameroon. S. Afr. J. Bot., 74: 629-638.

Panza V, Lainez V, Maldonado S, Maroder H. 2007. Effects of desiccation on Euterpe edulis Martius seeds. Biocell, 31(3): 383390.

Rodriguez OAV, Vazquez AP, Martinez AJ. 2014. Effects of seed weight and substrate on germination and growth of non-toxic Jatropha curcas L. seedlings. Ann. Res. Rev. Biol., 4(24): 4232-4245.

Russell T A. 1955. The kola of Nigeria and Cameroon. Trop. Agric., (Trinidad) 32: 210-241. 
Sacandé M, Golovina EA, van Aelst AC, Hoekstra FA. 2001. Variability loss of neem (Azadirachta indica) seeds associated with membrane phase behaviour. J. Exp. Bot., 52: 919-931.

Samarah NH. 2006. Effect of air-drying immature seeds in harvested pods on seed quality of common vetch (Vicia sativa L.). New Zealand J. Agric. Res., 49(3): 331-339.

Thomsen K. 2000. Handling of Desiccation and Temperature Sensitive Tree Teeds. DANIDA Forest Seed Centre: Humlebaek.

Viji V, Ratheesh CP, Nabeesa S, Jos TP. 2013. Influence of desiccation and associated metabolic changes during seed germination in Corypha umbraculifera Linn. J. Stress Physiol. Biochem., 9(3): 37-43.

Walters C, Pammenter NW, Berjak P, Crane J. 2001. Desiccation damage: "accelerated aging" and metabolism in desiccation tolerant and sensitive seeds. Seed Sci. Res., 11: 135-148.

Wesley-Smith J, Pammenter NW, Berjak P, Walters C. 2001. The effects of two drying rates on the desiccation tolerance of embryonic axes of recalcitrant Jackfruits (Artocarpus heterophyllus Lamk.) seeds. Ann. Bot., 88: 653-664. 